University of Nebraska - Lincoln

DigitalCommons@University of Nebraska - Lincoln

\title{
Induction of defense responses in tobacco by the protein Nep1 from Fusarium oxysporum
}

James C. Jennings

Beltsville Agricultural Research Center

Patricia C. Apel-Birkhold

Beltsville Agricultural Research Center

Norton M. Mock

Beltsville Agricultural Research Center

C. Jacyn Baker

Beltsville Agricultural Research Center, jacyn.baker@ars.usda.gov

James D. Anderson

Beltsville Agricultural Research Center

See next page for additional authors

Follow this and additional works at: https://digitalcommons.unl.edu/usdaarsfacpub

Part of the Agricultural Science Commons

Jennings, James C.; Apel-Birkhold, Patricia C.; Mock, Norton M.; Baker, C. Jacyn; Anderson, James D.; and Bailey, Bryan A., "Induction of defense responses in tobacco by the protein Nep1 from Fusarium oxysporum" (2001). Publications from USDA-ARS / UNL Faculty. 340.

https://digitalcommons.unl.edu/usdaarsfacpub/340

This Article is brought to you for free and open access by the U.S. Department of Agriculture: Agricultural Research Service, Lincoln, Nebraska at DigitalCommons@University of Nebraska - Lincoln. It has been accepted for inclusion in Publications from USDA-ARS / UNL Faculty by an authorized administrator of DigitalCommons@University of Nebraska - Lincoln. 


\section{Authors}

James C. Jennings, Patricia C. Apel-Birkhold, Norton M. Mock, C. Jacyn Baker, James D. Anderson, and Bryan A. Bailey 


\title{
Induction of defense responses in tobacco by the protein Nep1 from Fusarium oxysporum
}

\author{
James C. Jennings ${ }^{\mathrm{a}, 1}$, Patricia C. Apel-Birkhold ${ }^{\mathrm{b}, 2}$, Norton M. Mock ${ }^{\mathrm{c}}$, \\ C. Jacyn Baker ${ }^{\mathrm{c}}$, James D. Anderson ${ }^{\mathrm{a}, 3}$, Bryan A. Bailey ${ }^{\mathrm{b}, *}$ \\ ${ }^{a}$ Weed Science Laboratory, USDA/ARS, Beltsville Agricultural Research Center, Beltsville, MD 20705, USA \\ ${ }^{\mathrm{b}}$ Biocontrol of Plant Diseases Laboratory, USDA/ARS, Beltsville Agricultural Research Center, Beltsville, MD 20705, USA \\ ${ }^{c}$ Molecular Plant Pathology Laboratory, USDA/ARS, Beltsville Agricultural Research Center, Beltsville, MD 20705, USA
}

Received 22 March 2001; received in revised form 15 June 2001; accepted 19 June 2001

\begin{abstract}
Fusarium oxysporum produces a 24-kDa protein, Nep1, which induces necrosis and ethylene production in leaves of many dicot plant species. Detached Nicotiana tabacum L. cv. Xanthi leaves respond with concentration-dependent necrosis after infiltration with Nep1 or when Nep1 is taken up by the vascular tissue. This response follows the induction of ethylene biosynthesis and accumulation of ACC synthase and ACC oxidase transcripts. Pretreating the leaves with $100 \mu \mathrm{l} / 1$ ethylene prior to elicitation enhanced Nep1-induced ethylene production. Nep1 (208 nM) causes extensive necrosis of mature tobacco leaf tissue when applied to Xanthi tobacco as a foliar spray $\left(129 \mathrm{ml} / \mathrm{m}^{2}\right)$. Tobacco cell cultures respond to Nep1 by alkalization of the culture media, the accumulation of potassium in the media, oxygen uptake, induction of active oxygen species, and eventual cell death. The response of cultured tobacco cells to Nep1 is time- and concentration-dependent. Cell death was the same at $300 \mathrm{~min}$ for $5 \mathrm{ng} / \mathrm{ml}$ and higher concentrations, while $0.5 \mathrm{ng} / \mathrm{ml}$ had no effect on cell death. In the case of $\mathrm{O}_{2}$ uptake, cells responded to $0.5 \mathrm{ng} / \mathrm{ml}$ within minutes of treatment, but at a rate lower than $5 \mathrm{ng} / \mathrm{ml}$. The lower concentration of Nep1 did not induce an increase in $\mathrm{pH}$, $\mathrm{K}^{+}$ efflux, or increasing $\mathrm{H}_{2} \mathrm{O}_{2}$ accumulation in the culture media. Published by Elsevier Science Ireland Ltd.
\end{abstract}

Keywords: Active oxygen; Elicitor; Ethylene; Fusarium oxysporum; Hypersensitive response; Ion flux; Nep1; Nicotiana tabacum; Toxin

\section{Introduction}

Plants cells respond to various biotic chemical signals in their environment including non-self factors such as cell wall fragments on the surface of a pathogen, self determinants such as cell wall fragments that are released by a plant in response to an invading pathogen,

\footnotetext{
* Corresponding author. Present address: Alternate Crops and Systems Laboratory, Room 116, Building 007, BARC-West, Beltsville, MD 20705, USA. Tel.: + 1-301-504-7985; fax: + 1-301504-5968.

E-mail address: baileyb@ba.ars.usda.gov (B.A. Bailey).

${ }^{1}$ Present address: Monsanto Company, Mail Stop BB5 K, 700 Chesterfield Parkway North, Chesterfield, MO 63198, USA.

${ }^{2}$ Present address: Dow AgroScience, Building 306, 9330 Zionsville Rd, Indianapolis, IN 46268, USA.

${ }^{3}$ Present address: Plant Sciences Institute, Room 228, Bldg. 003, BARC-W, Beltsville, MD 20705, USA.
}

or compounds that are secreted by plant pathogens [1]. Pathogens may produce toxins [2-8] in various forms that promote disease development and many of which kill plant cells. Alternatively, pathogens may produce compounds such as proteins, small peptides, glycoproteins/peptides, or oligosaccharides [9-12] that activate mechanisms important in plant defense and are collectively known as elicitors. Many elicitors also kill plant cells. A 24-kDa extra-cellular protein (Nep1) that causes necrosis and induces ethylene biosynthesis in many dicot plants has been purified from culture filtrates of Fusarium oxysporum [13] and the protein partially sequenced and its gene cloned [14]. Subsequently, homologs to Nep1 have been isolated from Bacillis halodurans (GenBank accession \# BAB04114), Pythium aphanidermatum (GenBank accession \# AAD53944), and Phytophthora spp. (Thorsten Nürnberger, pers. commun.). 
Interestingly, it has been demonstrated for the first time that Nep1, an extra-cellular microbial protein, can be applied to many dicot weed species as a foliar spray where it causes extensive necrosis in a manner resembling the response to a contact herbicide [15]. In addition, it has been demonstrated that Nep1 remains active when co-applied with the chemical herbicides 2,4-D and glyphosate [16]. Nep1 has also been found to enhance disease development when co-applied with the bioherbicidal fungus Pleospora papaveracea to $\mathrm{Pa}$ paver somniferum [17]. Although it is well established that Nep1 causes necrosis and induces ethylene in many plant species, the response of plants to Nep1 at the cellular level has not been detailed.

Many elicitor proteins, in addition to being phytotoxic (i.e. they kill plant cells), also induce ethylene biosynthesis, and stimulate activity of other well-characterized cellular responses. Some of the plant responses induced by fungal elicitors include: ion fluxes across the plasma membrane, generation of AOS, changes in phosphorylation of specific proteins, transcription activation of various defense genes, induction of phytoalexin synthesis, ethylene biosynthesis, and localized cell death (hypersensitive response). The defense responses elicited by the EIX from Trichoderma viride have been well-characterized [18-21], and a group of small molecular weight proteins from Phytophthora species, known as elicitins, have also received considerable research attention [22-24]. Some of these proteins, Harpin being the most detailed [25-27], are capable of inducing systemic acquired resistance that protects plants against multiple diseases and even insects. Toxins, including a limited number of toxic proteins [7], can induce responses similar to those induced by elicitor proteins. The responses of plants to toxins can include electrolyte leakage [3,6], membrane depolarization [5,6], ethylene biosynthesis [2] and active oxygen production [8] in addition to cell death [2,6,7].

It is important to determine the relationship between the response of plant cells to Nep1 relative to other microbial proteins that kill plant cells so that yet unexplored uses of these proteins, such as natural herbicides or plant protectants, can be identified and exploited. In addition, it is important to examine Nepl's mode of action considering that proteins related to Nep1 have been identified in taxonomically divergent organisms. Our objective was to determine the induced effects of the $F$. oxysporum Nep1 protein in tobacco leaf tissue and cell-suspension culture. The induced effects that were examined include responses that require several hours to become visible, such as tissue necrosis and cell death; quicker responses that can be measured after several minutes such as the production of ethylene; and relatively rapid responses including proton uptake, potassium ion efflux, oxygen uptake, and active oxygen generation.

\section{Materials and methods}

\subsection{Purification of Nep1}

The isolate of $F$. oxysporum Schlechtend.:Fr. used for Nep1 purification was provided by Dr David C. Sands (Montana State University, Bozeman, MT, USA). One-liter cultures were grown for 7 days in Czapek-Dox broth with $1 \%$ casamino acids at $25{ }^{\circ} \mathrm{C}$ and $150 \mathrm{rev} . / \mathrm{min}$. Nep1 was purified from culture filtrates as previously described [13] using ultrafiltration and Fast Protein Liquid Chromatography (Pharmacia). Protein purification was monitored by Tricine-sodium dodecyl sulfate-PAGE [28] with silver staining [29]. Quantification of purified protein was based on the method of Bradford [30] with bovine serum albumin as the standard. The purified Nep1 was shown to be a single peptide when visualized on a silver-stained gel and it was recognized by antibodies raised against Nep1 [31].

\subsection{Nep1 treatment of leaves}

Nicotiana tabacum L. cv. Xanthi was started from seed and thinned to one plant per pot. Plants were grown in Jiffy-Mix Plus in 20 -cm pots under greenhouse conditions with natural lighting at $26{ }^{\circ} \mathrm{C}$. For the Nep1 treatments, leaves were chosen that were fully expanded and approximately the same size, age, and appearance. Leaves were treated with Nep1 by either infiltration, uptake through the petiole, or spraying in the presence of $0.2 \%(\mathrm{v} / \mathrm{v})$ Silwet L-77. Infiltration of Nep1 was always in $50 \mu \mathrm{l}$ of an aqueous solution delivered by syringe through the abaxial surface of the leaf. In some experiments, the Nep1 $(1 \mu \mathrm{g} / \mathrm{g}$ leaf fresh weight) was directly applied as a droplet to freshly cut petioles. After the droplet was absorbed, each petiole was then placed in water and the leaf was sealed inside a 475-ml jar. Jars were sealed with a lid that was equipped with a septum to allow for the withdrawal of air samples by needle and syringe. For experiments involving ethylene pretreatment, tobacco plants were pretreated for $16 \mathrm{~h}$ in air or $100 \mu \mathrm{l} / 1$ ethylene prior to Nep1 treatment of the leaves. Ethylene production was quantified by gas chromatography with flame ionization detection (Hewlett-Packard 5890A Gas Chromatograph). The column was a $3 \mathrm{~m}$ Hayesep D 80/100 (made for Hewlett-Packard by Hayes Separations) heated to $80{ }^{\circ} \mathrm{C}$. Helium was the carrier gas and the minimum level of detection was approximately $10 \mathrm{nl} / 1$ ethylene in $1 \mathrm{ml}$. In the experiments where plants were sprayed directly with Nep1 (208 nM at a rate of 129 $\mathrm{ml} / \mathrm{m}^{2}$ ), photographs were taken 1 and 5 days after treatment. 


\subsection{RNA isolation and northern analysis}

Detached tobacco leaves were treated with $1 \mu \mathrm{g} / \mathrm{g}$ Nep1 via the petiole as described above, then frozen in liquid $\mathrm{N}_{2}$ after $3 \mathrm{~h}$ of treatment. Total RNA was extracted from control and Nep1-treated leaves according to the method of Yoder [32] except that cresol and glass beads were omitted from the protocol. Thirty micrograms of each total RNA sample were separated by $1.2 \%$ denaturing agarose gel electrophoresis [33]. RNA was blotted onto a Nytran nylon membrane using the TurboBlotter System (Schleicher \& Schuell) and crosslinked to the membrane using an UV Stratalinker 1800 from Stratagene. The RNA blot was sequentially probed with ${ }^{32} \mathrm{P}$-labeled b-actin (mouse cDNA from Stratagene), ACC oxidase, and ACC synthase. The ACC oxidase gene was a 604-bp fragment that was PCR-amplified from a Xanthi cDNA library [34]. The synthase gene was also obtained from a Xanthi cDNA library and was cloned into plasmid pTACC-13 [35]. Probes were prepared using $\left[{ }^{32} \mathrm{P}\right] \mathrm{dCTP}$ (Amersham) and the Oligolabelling Kit from Pharmacia Biotech. The blot was hybridized with each probe individually overnight at $50{ }^{\circ} \mathrm{C}$ in $5 \times$ SSPE, $2 \times$ Denhardt's Solution, $0.1 \%$ SDS, and $0.1 \mathrm{mg} / \mathrm{ml}$ denatured salmon sperm DNA. After each hybridization, the blot was washed twice in $2 \times \mathrm{SSPE} / 0.1 \% \mathrm{SDS}$ at room temperature for each 10-min wash and exposed to high-speed X-ray film. The radionucleotides were stripped from the blot between hybridizations by boiling for $10 \mathrm{~min}$ in $0.5 \% \mathrm{SDS}$.

\subsection{Cell culture experiments}

Suspension cells, originally isolated from pith cells of $N$. tabacum cv. Hicks, were maintained in Schenk and Hildebrandt medium [36] at $27^{\circ} \mathrm{C}$ on a rotary shaker at $150 \mathrm{rev} . / \mathrm{min}$. Cells were transferred into fresh medium every 4 days. For Nep1 treatments, cells were used 2-3 days after transfer. Cells were washed and resuspended in Assay Buffer (0.5 mM MES (pH 6.0), $0.5 \mathrm{mM} \mathrm{CaCl}_{2}$, $0.5 \mathrm{mM} \mathrm{K}_{2} \mathrm{SO}_{4}$, and $175 \mathrm{mM}$ mannitol) to a final concentration of $0.5-100 \mathrm{ng} / \mathrm{ml}$ for analysis of cell death, $\left[\mathrm{O}_{2}\right], \mathrm{pH},\left[\mathrm{K}^{+}\right]$, and $\left[\mathrm{H}_{2} \mathrm{O}_{2}\right]$ measurements.

Calibration of the $\mathrm{O}_{2}$ electrodes (Microelectrodes Inc., Londonderry, NH, USA) and data acquisition (National Instruments Corp., Austin, TX, USA) were performed as previously described [37]. Electrodes were mounted in $50-\mathrm{ml}$ tricornered polypropylene beakers that were stoppered and contained $25 \mathrm{ml}$ of suspension cells, each. Oxygen uptake was continuously monitored after tobacco suspension cells were treated with Nep1. Final concentrations of Nep1 were $0,0.5,5,50$, and 100 $\mathrm{ng} / \mathrm{ml} . \mathrm{pH}$ and $\mathrm{K}^{+}$electrodes (Microelectrodes Inc.) were connected to the same data acquisition hardware and software as described for the $\mathrm{O}_{2}$ electrodes, and the data were similarly collected.
Active oxygen production by Nep1-treated suspension cells was monitored by the method of Orlandi et al. [38]. The assay contained both $80 \mathrm{mM}$ Luminol and 10 $\mathrm{mg} / \mathrm{ml}$ horseradish peroxidase, and measurements of $\left[\mathrm{H}_{2} \mathrm{O}_{2}\right]$ were with a LKB 1251 luminometer (Turku, Finland). Death of tobacco cells was determined using Evans Blue as previously described [39]. Cell samples were measured prior to Nep1 treatment, and then at 90 and $300 \mathrm{~min}$ after treatment.

\section{Results}

\subsection{Leaf treatments}

Tobacco leaves infiltrated with Nep1 from $F$. oxysporum responded with concentration-dependent necrosis (Fig. 1). The number of tobacco cells that were affected by Nep1 was positively correlated to the amount of Nep1 infiltrated into the leaf. Necrosis was visually apparent after treatment with concentrations as low as $6 \mathrm{ng}$ of purified Nep1 in $50 \mu \mathrm{l}$. Leaf tissue remained water-soaked for at least 1 day after treatment and necrosis was evident within 2 days. By that time the tissue had dried out and turned yellowish brown. The effect of Nep1 remained fairly localized to the region of treatment.

When Nep1 was taken up by the vascular system of the petiole, necrosis spread throughout the entire leaf, and in particular surrounded the veins (Fig. 2). Widespread necrosis was apparent after treatment of leaves with as little as $0.5 \mu \mathrm{g}$ of Nep1 per $\mathrm{g}$ fresh leaf weight. Increasing concentrations of Nep1 caused increasing levels of necrosis. After Nep1 treatment, the margins of a leaf turned dark brown, desiccated, and curled.

Another response of detached tobacco leaves to Nep1 was the biosynthesis of the plant hormone ethylene (Fig. $3)$. Induction of ethylene production was positively correlated to the concentration of Nep1 used in the treatment, with higher concentrations of Nep1 inducing greater amounts of ethylene production. The peak in the rate of ethylene production was approximately $3 \mathrm{~h}$ after treatment. Induction of ethylene biosynthesis is associated with the activation of at least two genes: ACC synthase and ACC oxidase (Fig. 4). Northern blot analysis confirmed that Nep1 treatment induced transcripts for both of these ethylene biosynthetic enzymes. Transcripts for ACC synthase were induced several-fold within $3 \mathrm{~h}$ after treatment of leaves with $1 \mu \mathrm{g} / \mathrm{g}$ Nep1. Transcripts for ACC oxidase were virtually undetectable before Nep1 treatment but were dramatically up-regulated with elicitation. Also, if intact tobacco plants were pretreated in an atmosphere of $100 \mu \mathrm{l} / \mathrm{l}$ ethylene prior to elicitation of their leaves, the level of induced ethylene production was increased approximately threefold (Fig. 5). 


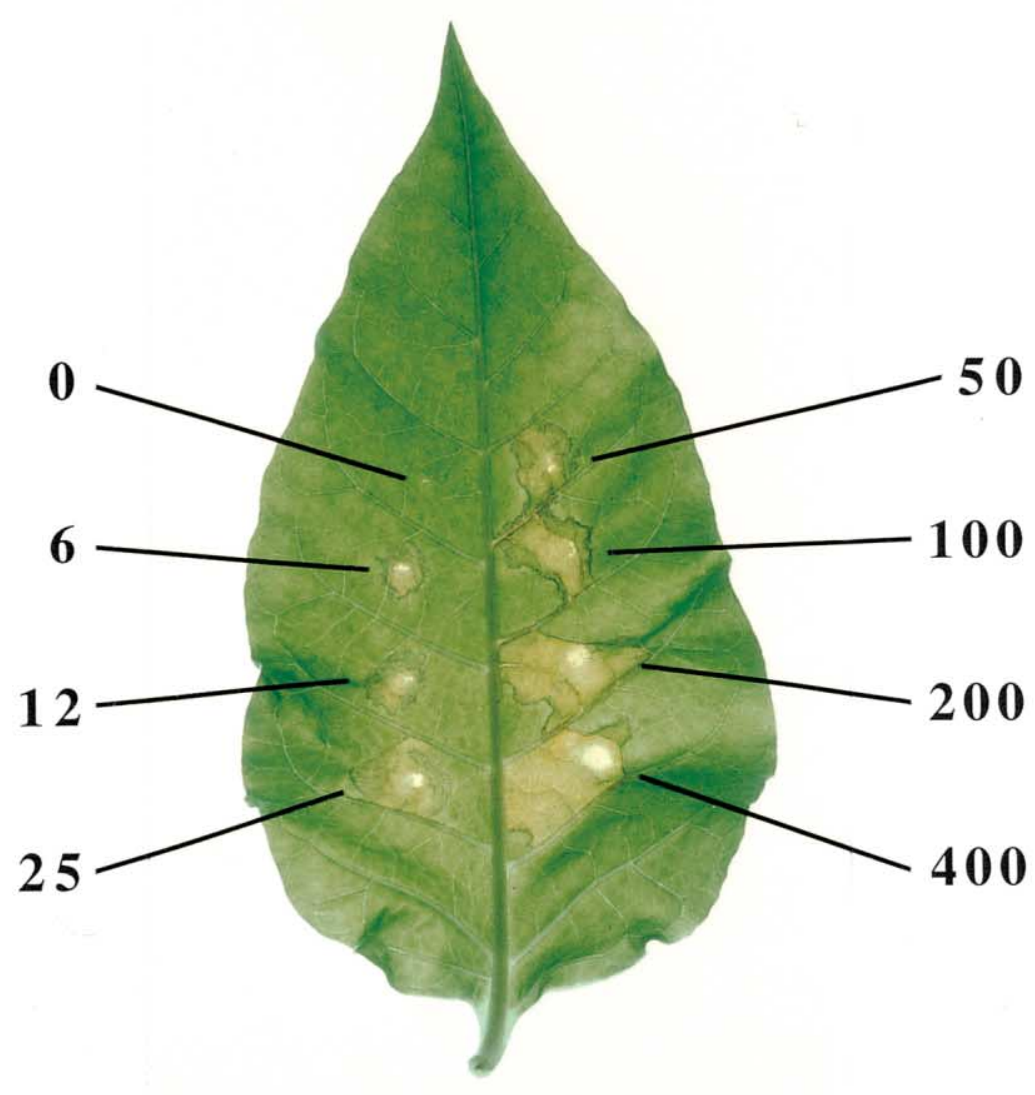

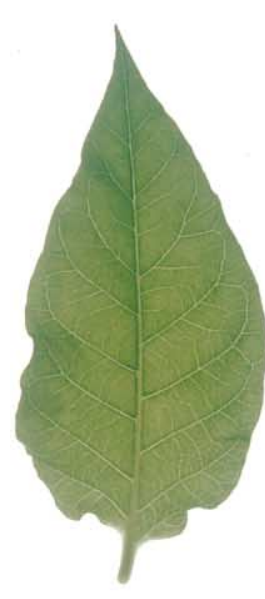

0

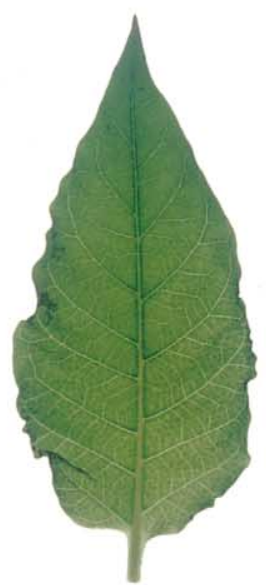

0.5

Fig. 1

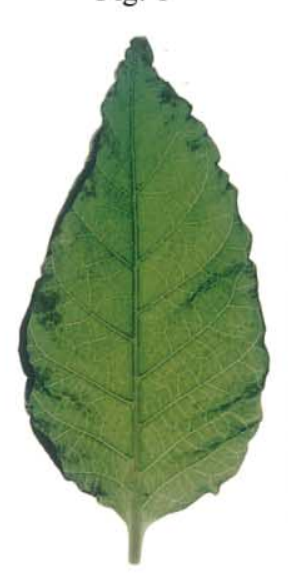

1.0

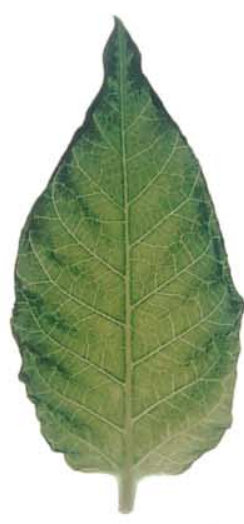

2.0

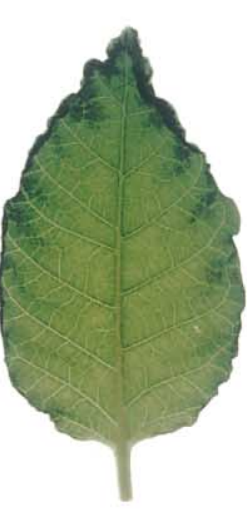

4.0

Fig. 2

Fig. 1. Necrosis induced by infiltration of a tobacco leaf with the protein from $F$. oxysporum. Each number corresponds to nanograms of purified protein that were infiltrated into the leaf in a total volume of $50 \mu \mathrm{l}$. The photograph was taken 2 days after treatment.

Fig. 2. Necrosis induced in detached tobacco leaves by Nep1 after treatment of their cut petioles. Each number corresponds to micrograms of protein per $\mathrm{g}$ fresh leaf weight. The photograph was taken 2 days after treatment. 


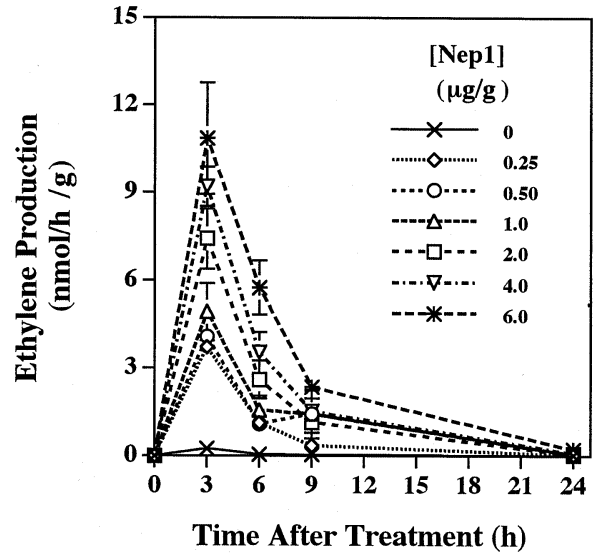

Fig. 3. Rates of ethylene production by tobacco leaves after treatment with several concentrations of Nep1. Nep1 was applied to cut petioles based on the fresh weight of each leaf. Ethylene production is expressed as nmol per $\mathrm{h}$ per $\mathrm{g}$ fresh leaf weight.

\subsection{Intact plant treatments}

Tobacco seedlings were quite sensitive to Nep1 in the presence of $0.2 \%$ Silwet L-77. Plants started to show necrosis within $24 \mathrm{~h}$ of treatment. Five days after treatment, axially buds started to grow and developing leaves did not show effects of Nep1; however, mature vegetative tissue was severely damaged (Fig. 6).

\subsection{Cell culture experiments}

The viability of tobacco suspension cells treated with Nep1 was monitored using an Evans Blue dye exclusion

\section{$\beta$-Actin}

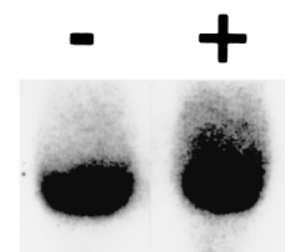

\section{ACC Synthase}

\section{ACC Oxidase}

Fig. 4. Expression of ACC synthase and ACC oxidase transcripts in control $(-)$ and Nep1-treated $(+)$ tobacco leaves. Leaves were treated with buffer alone or $1 \mu \mathrm{g} / \mathrm{g}$ Nepl and harvested after $3 \mathrm{~h}$. Hybridization to b-Actin is shown as a control.

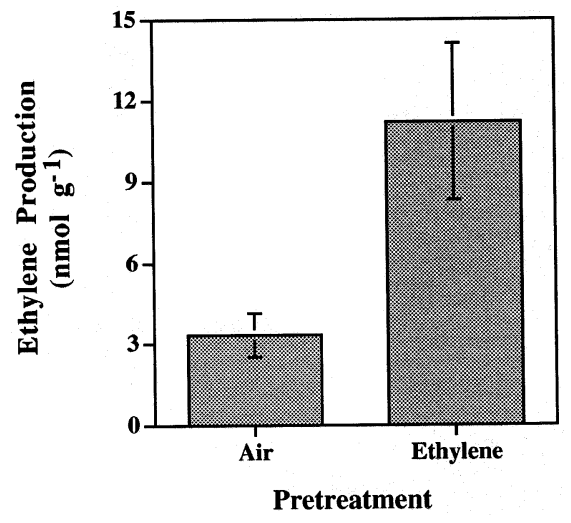

Fig. 5. Effect of ethylene pretreatment on Nepl-induced ethylene production. Tobacco plants were pretreated for $16 \mathrm{~h}$ in air or $100 \mu \mathrm{l} / 1$ ethylene prior to treatment with $1 \mu \mathrm{g} / \mathrm{g}$ of Nep1. Total ethylene production was measured $24 \mathrm{~h}$ after treatment.

assay (Fig. 7A). When cells were treated with concentrations of Nep1 greater than or equal to $5 \mathrm{ng} / \mathrm{ml}$, significant reduction in viability could be detected within $5 \mathrm{~h}$. Nep1 at a concentration of $0.5 \mathrm{ng} / \mathrm{ml} \mathrm{did}$ not induce detectable cell death. In parallel samples, $\mathrm{O}_{2}$ uptake was measured (Fig. 7B). Within minutes of adding 5-100 ng/ml Nep1, $\mathrm{O}_{2}$ uptake was enhanced. The increased rate of $\mathrm{O}_{2}$ utilization remained greater than control or $0.5 \mathrm{ng} / \mathrm{ml}$ treatments. After about 90 min, $\mathrm{O}_{2}$ utilization by Nep1-treated cells appeared to stop. This indicates that the respiratory rates of the treated cells had been significantly reduced, though the cell membranes were still intact since Evans Blue was excluded from the cells (Fig. 7A).

Changes in extracellular $\mathrm{pH}$ and $\mathrm{K}^{+}$concentrations were measured in Nep1-treated cell cultures (Fig. 8). Within minutes of treatment of tobacco cells with concentrations of Nep1 greater than or equal to $5 \mathrm{ng} / \mathrm{ml}$, the external $\mathrm{pH}$ and $\left[\mathrm{K}^{+}\right]$increased significantly. The $\mathrm{K}^{+} / \mathrm{H}^{+}$exchange response was saturated with 50 and $100 \mathrm{ng} / \mathrm{ml} \mathrm{Nep1.}$

An immediate burst of $\mathrm{H}_{2} \mathrm{O}_{2}$ was detected by Luminol chemiluminescence in Nep1-treated cell cultures (Fig. 9). A strong response, was observed with $5 \mathrm{ng} / \mathrm{ml}$ Nep1, and the response appeared to reach a maximum

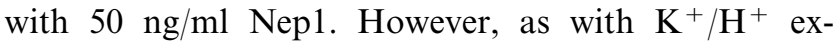
change and cell death responses, a Nepl concentration of $0.5 \mathrm{ng} / \mathrm{ml}$ did not induce the detectable production of $\mathrm{H}_{2} \mathrm{O}_{2}$.

\section{Discussion}

Nep1 is the primary necrosis inducing peptides found in culture filtrates of several $F$. oxysporum formae speciales, Fusarium avenacium and Fusarium acuminatum [31]. Nep1 induces severe necrosis in detached leaves of tobacco and many other plant species [13] when 
infiltrated into the leaf tissue (Fig. 1) or delivered through the vascular system (Fig. 2). The pattern of necrosis indicates movement of this protein or other soluble signal throughout the vascular tissue when Nep1 is applied to the petiole (Fig. 2) similar to the pattern observed for EIX in tobacco [40,41]. As with intact tobacco leaf tissue (Figs. 1 and 2), tobacco cell-suspension cultures respond to Nepl with cell death (Fig. 7A). More rapid physiological responses to Nep1 included $\mathrm{O}_{2}$ uptake, AOS production, and a $\mathrm{K}^{+} / \mathrm{H}^{+}$ response (Fig. 7B). The minimum amount of Nep1 required to induce cell death within $5 \mathrm{~h}$ was $5 \mathrm{ng} / \mathrm{ml}$. The sensitivity of tobacco cells to Nep1 is similar to, if not greater than, their sensitivity to xylanase [19] and cryptogein [24]. Similar specific activity levels have been demonstrated for the Avr9 elicitor in Cf-9 tomato [42], the Pell 3 pectate lyase/elicitor in tobacco [43], and the host/cultivar specific toxin Tox $\mathrm{A}$ in wheat [7] when variations in experimental systems are taken into account.

An increase in extracellular $\mathrm{pH}$ and $\mathrm{K}^{+}$concentration [44,45] is associated with the hypersensitive response induced by an incompatible plant/pathogen interaction. Mathieu et al. [46] have characterized an increase in cytoplasmic $\mathrm{H}^{+}$as a common early response of tobacco cells to elicitors and also showed that the uptake of $\mathrm{H}^{+}$by tobacco cells was mediated by protein phosphorylation. Proton-ATPases and G proteins may also be involved in the elicitor-induced import of $\mathrm{H}^{+}$ [47], and the $\mathrm{H}^{+}$import observed with the $24-\mathrm{kDa}$ protein is likely linked to the $\mathrm{K}^{+}$efflux (Fig. 8). It is unclear if simple destruction of membrane integrity would yield similar kinetics for the changes in extra-cellular $\mathrm{pH}$ and $\mathrm{K}^{+}$concentration observed with Nep1 or elicitors. Both nonspecific and host specific toxins have been shown to alter membrane permeability, in some cases by membrane depolarization $[3,6]$, resulting in loss of electrolytes [3,5].

Increased production of AOS is also associated with hypersensitive cell death resulting from incompatible plant/pathogen interactions [48-52]. Tobacco suspension cells treated with Nep1 produced relatively large amounts of $\mathrm{H}_{2} \mathrm{O}_{2}$ (Fig. 9). The minimum threshold of Nep1 required to induce $\mathrm{H}_{2} \mathrm{O}_{2}$ production was around $5 \mathrm{ng} / \mathrm{ml}$. At this concentration, there was a delay in the production of $\mathrm{H}_{2} \mathrm{O}_{2}$ when compared to treatments with 50 and $100 \mathrm{ng} / \mathrm{ml}$. The delay could be explained by inherent antioxidant mechanisms within the plant cells that were able to counter any initial $\mathrm{H}_{2} \mathrm{O}_{2}$ burst induced by the low concentration of Nep1. May et al. [53] measured induced responses in near-isogenic lines of tomato by race-specific $A v r$-gene products from $C$. fulvum. The elicitors induced the production of reactive oxygen species, including $\mathrm{H}_{2} \mathrm{O}_{2}$, and caused increases in glutathione levels and lipoxygenase enzyme activity. Kieffer et al. [54] demonstrated the possible involve-

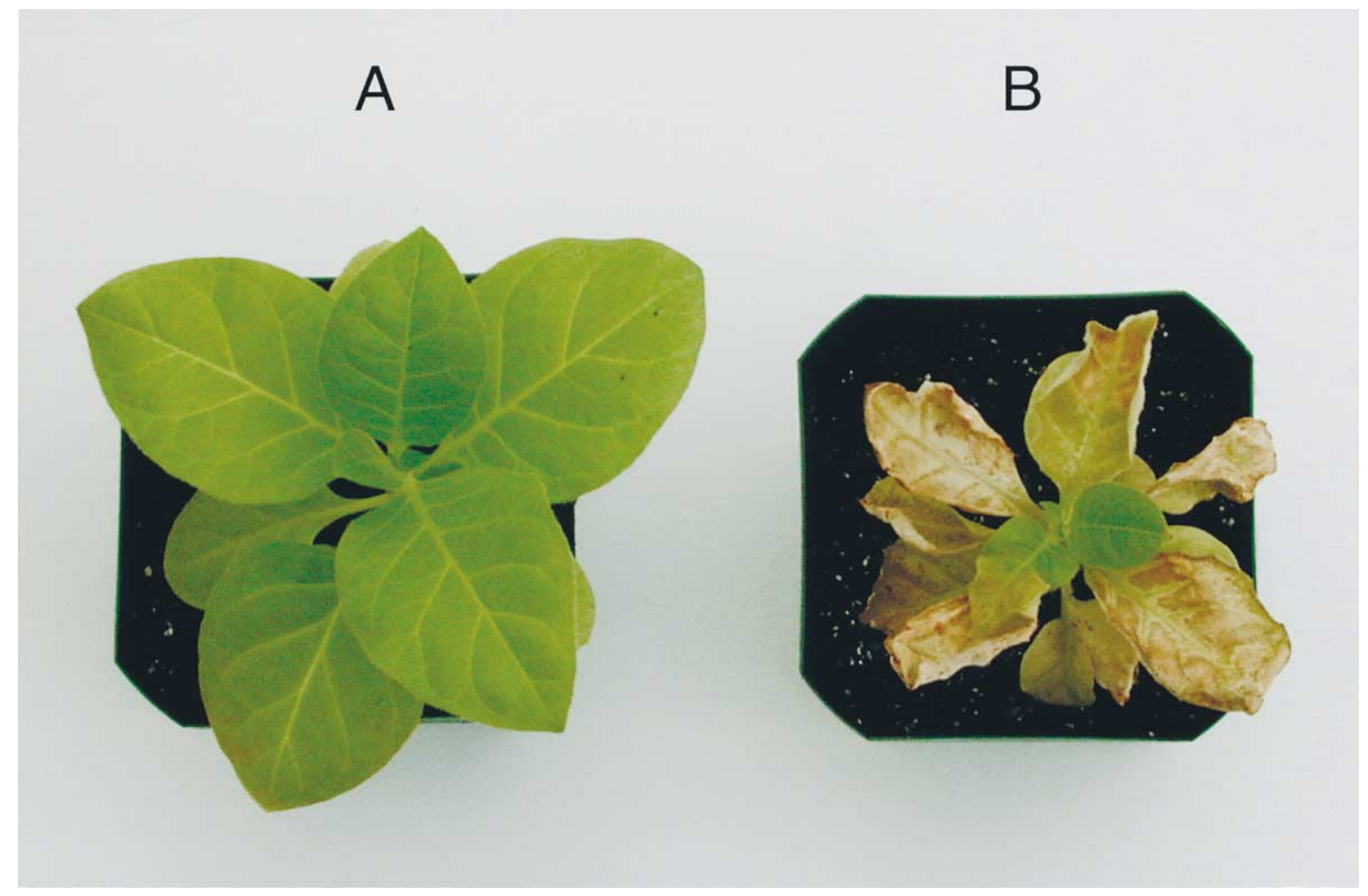

Fig. 6. Necrosis induced by spraying tobacco plants with the Nep1 from $F$. oxysporum at. The plant on the left was treated with $0.2 \%$ Silwet L-77 and the plant on the right with Nep1 (208 nM Nep1 in $0.2 \%$ Silwet L-77) at a rate of $129 \mathrm{ml} / \mathrm{m}^{2}$. The photograph was taken 5 days after treatment. 

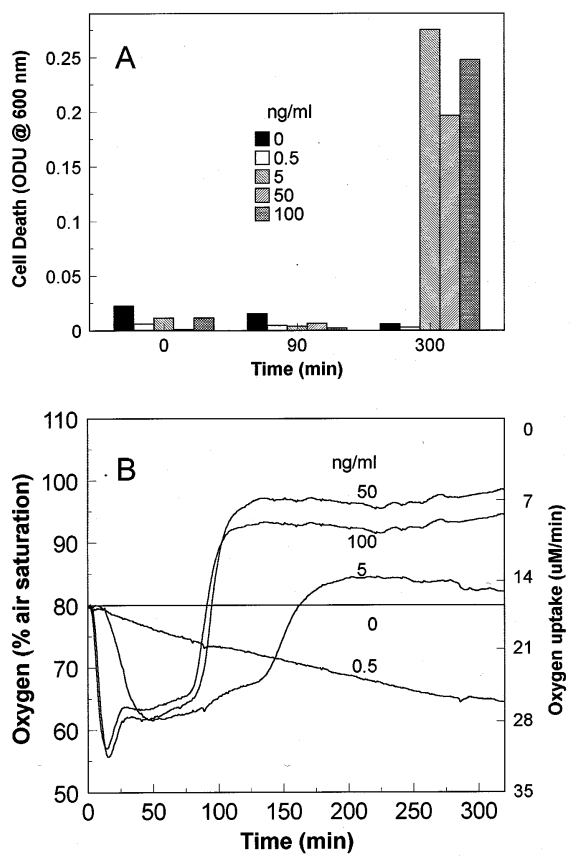

Fig. 7. Loss of tobacco cell viability (A) and oxygen uptake (B) after treatment of cell-suspension cultures with Nep1. Cultures were

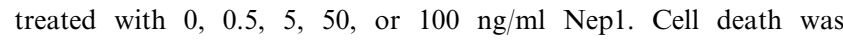
estimated by an Evans Blue retention assay. Oxygen uptake was continuously monitored by an oxygen electrode.

ment of small $\mathrm{G}$ proteins in cryptogein-induced AOS generation in tobacco cells. The protein Harpin, an elicitor produced by Erwinia species, has also been

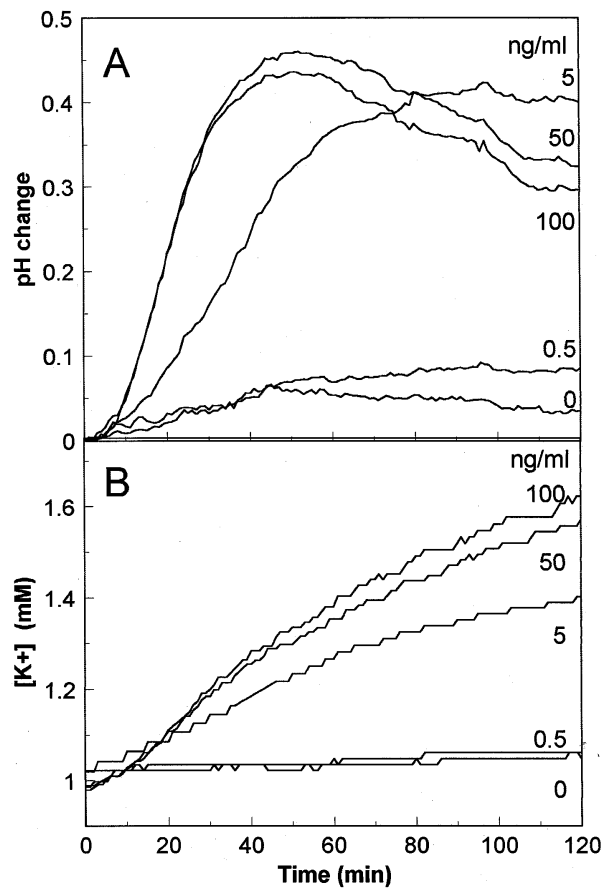

Fig. 8. The exchange of protons (A) and potassium ions (B) was monitored in tobacco suspension cells treated with various concentrations of Nep1. pH and potassium concentrations were continuously measured with specific electrodes.

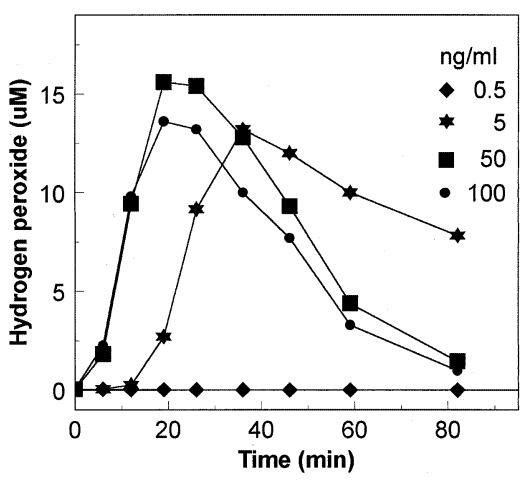

Fig. 9. Active oxygen generation by tobacco suspension cells treated with various concentrations of Nep1. Hydrogen peroxide was detected by a luminol-dependent chemiluminescent technique.

shown to induce AOS production and $\mathrm{K}^{+} / \mathrm{H}^{+}$exchange in a tobacco cell-suspension system [55]. Harpin has been shown to elicit the hypersensitive response in tobacco and other non-host species [56,57]. Harpins are capable of inducing systemic acquired resistance that protects plants against multiple diseases and even insects [25-27]. In contrast, Nep1 has been shown to promote disease development in at least one plantpathogen interaction [17] supporting evidence that AOS may function to promote disease depending upon the pathogen and plant involved [58]. Active oxygen is likely to be produced at some point in the process of cell death regardless of the cause [59]. The toxins Cercosporin, produced by the plant pathogenic Cercospora fungi, generates singlet oxygen when exposed to light [8]. Unfortunately, the models and methods used when studying active oxygen production by compounds characterized as toxins limit direct comparison to results presented here as well as the 'oxidative burst' associated with elicitor induced necrosis.

The research reported above demonstrates that Nep1 from $F$. oxysporum elicits many of the same plant responses induced by well-characterized elicitors. The techniques used in characterizing elicitors are not in general use where toxins are concerned making comparisons difficult. In some cases, the perception of toxins [3] and elicitors [11,21] is proposed to be mediated by receptors or, alternatively, function by direct interactions with membranes $[3,5,60]$. The primary character used in characterizing a compound as an elicitor or toxin rest on whether it induces 'defense responses', inhibiting disease development, or induces 'susceptibility', promoting disease development. It is even established in the literature that elicitors of active oxygen can in some cases promote disease development [58]. Growing evidence suggests that cell death induced by both toxins [61] and elicitors [62,63] share a commonality with programmed cell death observed in animals. Individual pathways involved in the induction of 
cell death by both toxins and elicitors may be similar or even shared.

It has been demonstrated that Nep1 causes extensive foliar necrosis when applied as a foliar spray to dicot weed species $[15,16]$, an activity that has not been demonstrated for other necrosis inducing proteins whether toxins or elicitors. Critical to the response of plants to foliar sprays with Nep1 is the inclusion of surfactants (Silwet-L77) which appears to allow penetration of the leaf epidermal layer through stomata $[15,16]$. Nep1 promotes disease in at least one plantpathogen interaction [17] and is compatible with some herbicides [16]. Based on results presented here, it is difficult to distinguish the response of plants to Nep1 from the response of plants to necrosis-inducing elicitors at the cellular level. Comparisons to toxin-induced responses remain unclear. It is unknown if well-characterized necrosis inducing proteins, whether classified as elicitors or toxins, have herbicidal activity when applied in foliar sprays in a manner similar to Nep1. It is likely that other microbial proteins will be identified with activity similar to Nep1, since at the cellular level, the responses to Nepl are not unique. The recent identification of proteins related to Nep1 in taxonomically divergent microbes demonstrates the existence of a family of genes. Although, the function of Nep1 in microbial development has yet to be characterized, these studies provide a foundation for future studies of Nep1 and its gene family and for the identification of proteins with similar herbicidal activity.

\section{Acknowledgements}

We thank Dr David C. Sands (Montana State University) for supplying the isolate of $F$. oxysporum used for the Nep1 purification. We also gratefully acknowledge H. David Clark (Weed Science Laboratory) for providing excellent photography and technical assistance. Mention of a trademark or proprietary product does not constitute a guarantee or warranty of the product by the U.S. Department of Agriculture and does not imply its approval to the exclusion of other products that may also be suitable.

\section{References}

[1] W. Knogge, Fungal infection of plants, Plant Cell 8 (1996) 1711-1722.

[2] D.G. Gilchrist, H. Wang, R.M. Bostock, Sphingosine-related mycotoxins in plant and animal diseases, Can. J. Bot. 73 (1994) S459-S467.

[3] K. Kohmoto, H. Otani, Host recognition by toxigenic plant pathogens, Experientia 47 (1991) 755-764.

[4] H. Otani, M. Kodama, K. Kohmoto, Physiological and molecular aspects of Alternaria host-specific toxins and plant interac- tions, in: D. Mills, et al. (Eds.), Molecular Aspects of Pathogenicity and Resistance: Requirement for Signal Transduction, The American Phytopathological Society, St. Paul, MN, 1996, pp. 257-267.

[5] J. Rotem, The biotic and physiological components of pathogenesis, in: J. Rotem (Ed.), The Genus Alternaria; Biology, Epidemiology, and Pathogenicity, The American Phytopathological Society, St. Paul, MN, 1998, pp. 95-118.

[6] H. Schroter, A. Novacky, V. Macko, Effect of Helminthosporium sacchari-toxin on cell membrane potential of susceptible sugarcane, Physiol. Plant Pathol. 26 (1985) 165-174.

[7] R.P. Tuori, T.J. Wolpert, L.M. Ciuffetti, Purification and immunological characterization of toxic components from cultures of Pyrenophora tritici-repentis, Mol. Plant Microbe Interact. 8 (1995) 41-48.

[8] J.D. Williamson, J.G. Scandalios, Differential response of maize catalases and superoxide dismutases to the photoactivated fungal toxin cercosporin, Plant J. 2 (1992) 351-358.

[9] F. Cotr, M.G. Hahn, Oligosaccharins: structures and signal transduction, Plant Mol. Biol. 26 (1994) 1379-1411.

[10] J. Ebel, E.G. Cosio, Elicitors of plant defense responses, Int. Rev. Cytol. 148 (1994) 1-36.

[11] M.G. Hahn, Microbial elicitors and their receptors in plants, Annu. Rev. Phytopathol. 34 (1996) 387-412.

[12] P. Ricci, F. Panabieres, P. Bonnet, N. Maia, M. Ponchet, J.-C. Devergne, A. Marais, L. Cardin, M.L. Milat, J.P. Blein, Proteinaceous elicitors of plant defense responses, in: B. Fritig, M. Legrand (Eds.), Mechanisms of Plant Defense Responses, Kluwer, Dordrecht, 1993, pp. 121-135.

[13] B.A. Bailey, Purification of a protein from culture filtrates of Fusarium oxysporum that induces ethylene and necrosis in leaves of Erythroxylum coca, Phytopathology 85 (1985) 1250-1255.

[14] A.J. Nelson, P.C. Apel-Birkhold, B.A. Bailey, Sequence announcements, Plant Mol. Biol. 38 (1998) 911-912.

[15] J.C. Jennings, P.C. Apel-Birkhold, B.A. Bailey, J.D. Anderson, Induction of ethylene biosynthesis and necrosis in weed leaves by a Fusarium oxysporum protein, Weed Sci. 48 (2000) 7-14.

[16] B.A. Bailey, R. Collins, J.D. Anderson, Factors influencing the herbicidal activity of Nep1, a fungal protein that induces the hypersensitive response in Centaurea maculosa (spotted knapweed), Weed Science, 2000, in press.

[17] B.A. Bailey, P.C. Apel-Birkhold, O.O. Akingbe, J.L. Ryan, N.R. O'Neill, J.A. Anderson, Nep1 protein from Fusarium oxysporum enhances biological control of opium poppy by Pleospora papaveracea, Phytopathology 90 (2000) 812-818.

[18] J.D. Anderson, F.C. Cardinale, J.C. Jennings, H.A. Norman, A. Avni, U. Hanania, B.A. Bailey, Involvement of ethylene in protein elicitor-induced plant responses, in: A.K. Kanellis, et al. (Eds.), Biology and Biotechnology of the Plant Hormone Ethylene, Kluwer, Dordrecht, 1997, pp. 267-274.

[19] B.A. Bailey, R.F. Korcak, J.D. Anderson, Alterations in Nicotiana tabacum 1. cv Xanthi cell membrane function following treatment with an ethylene biosynthesis-inducing endoxylanase, Plant Physiol. 101 (1993) 1081-1088.

[20] K.D. Chapman, A. Conyers-Jackson, R.A. Moreau, S. Tripathy, Increased $\mathrm{N}$-acylphosphadidylethanoloamine biosynthesis in elicitor-treated tobacco cells, Physiol. Plant. 95 (1995) 120-126.

[21] U. Hanania, A. Avni, High-affinity binding site for ethylene-inducing xylanase elicitor on Nicotiana tabacum membranes, Plant J. 12 (1997) 113-120.

[22] P. Bonnet, E. Bourdon, M. Ponchet, J.-P. Blein, P. Ricci, Acquired resistance triggered by elicitins in tobacco and other plants, Eur. J. Plant Pathol. 102 (1996) 181-192.

[23] L.M. Yu, Elicitins from Phytophthora and basic resistance in tobacco, Proc. Natl. Acad. Sci. USA 92 (1995) 4088-4094.

[24] P. Ricci, F. Panabieres, P. Bonnet, N. Maia, M. Ponchet, J.-C. Devergne, A. Marais, L. Cardin, M.L. Milat, J.P. Blein, 
Proteinaceous elicitors of plant responses, in: B. Fritig, M. Legrand (Eds.), Mechanisms of Plant Defense Responses, Kluwer, Dordrecht, 1993, pp. 121-135.

[25] N.E. Strobel, C. Ji, S. Gopalan, J.A. Kuc, Induction of systemic acquired resistance in cucumber by Pseudomonas syringae pv. syringae $61 \mathrm{HrpZ}_{\mathrm{P}_{\mathrm{ss}}}$ protein, Plant J. 9 (1996) 431-439.

[26] Z.-M. Wei, S.V. Beer, Harpin from Erwinia amylovora induces plant resistance, Acta Hort. 411 (1996) 223-225.

[27] Z. Xie, Z. Chen, Harpin-induced hypersensitive cell death is associated with altered mitochondrial functions, Mol. Plant Microbe Interact. 2 (2000) 183-190.

[28] H. Schägger, G. von Jagow, Tricine-sodium dodecyl sulfatepolyacrylamide gel electrophoresis for the separation of proteins in the range from 1 to $100 \mathrm{kDa}$, Anal. Biochem. 166 (1987) $368-379$.

[29] W. Wray, T. Boulikas, V.P. Wray, R. Hancock, Silver staining of proteins in polyacrylamide gels, Anal. Biochem. 118 (1981) 197203.

[30] M.M. Bradford, A rapid and sensitive method for the quantification of microgram quantities of protein utilizing the principle of protein-dye binding, Anal. Biochem. 72 (1976) 248-254.

[31] B.A. Bailey, J.C. Jennings, J.D. Anderson, The $24-\mathrm{kD}$ protein from Fusarium oxysporum f.sp. erythroxyli: occurrence in related fungi and the effect of growth medium on its production, Can. J. Microbiol. 43 (1997) 45-55.

[32] O.C. Yoder, Cochliobolus heterostrophus, cause of southern corn leaf blight, Adv. Plant Pathol. 6 (1988) 93-112.

[33] J. Sambrook, E.F. Fritsch, T. Maniatis, Molecular Cloning: A Laboratory Manual, 2nd edn, Cold Spring Harbor Laboratory Press, Cold Spring Harbor, New York, 1989, pp. 7.43-7.45.

[34] A. Avni, B.A. Bailey, A.K. Mattoo, J.D. Anderson, Induction of ethylene biosynthesis in Nicotiana tabacum by a Trichoderma viride xylanase is correlated to the accumulation of 1-aminocyclopropane-1-carboxylic acid (ACC) synthase and ACC oxidase transcripts, Plant Physiol. 106 (1994) 1049-1055.

[35] B.A. Bailey, A. Avni, N. Li, A.K. Mattoo, J.D. Anderson, Nucleotide sequence of the Nicotiana tabacum cv Xanthi gene encoding 1-aminocyclopropane-1-carboxylate synthase, Plant Physiol. 100 (1992) 1615-1616.

[36] R.U. Schenk, A.C. Hildebrandt, Medium and techniques for induction and growth of monocotyledonous and dicotyledonous plant cell cultures, Can. J. Bot. 50 (1972) 199-204.

[37] C.J. Baker, N.M. Mock, K. Deahl, J. Domek, Monitoring the rate of oxygen consumption in plant cell suspensions, Plant Cell Tissue Organ Cult. 51 (1997) 111-117.

[38] E.W. Orlandi, S.W. Hutcheson, C.J. Baker, Early physiological responses associated with race-specific recognition in soybean leaf tissue and cell suspensions treated with Pseudomonas syringae pv. glycinea, Physiol. Mol. Plant Pathol. 40 (1992) 173-180.

[39] C.J. Baker, N.M. Mock, An improved method for monitoring cell death in cell suspension and leaf disc assays using Evans blue, Plant Cell Tissue Organ Cult. 39 (1994) 7-12.

[40] B.A. Bailey, R. Taylor, J.F.D. Dean, J.D. Anderson, Ethylene biosynthesis-inducing endoxylanase is translocated through the xylem of Nicotiana tabacum cv Xanthi plants, Plant Physiol. 97 (1991) 1181-1186.

[41] A. Sharon, B.A. Bailey, J.P. McMurtry, R. Taylor, J.D. Anderson, Characteristics of ethylene biosynthesis-inducing xylanase movement in tobacco leaves, Plant Physiol. 100 (1992) 2059-2065.

[42] P. Piedras, K.E. Hammond-Kosack, K. Harrison, J.D.G. Jones, Rapid Cf-9- and Avr9-dependent production of active oxygen species in tobacco suspension cultures, Mol. Plant Microbe Interact. 11 (1998) 1155-1166.

[43] V.E. Shevchik, M. Boccara, R. Vedel, N. Hugouvieux-Cotte-Pattat, Processing of the pectate lyase Pell by extracellular proteases of Erwinia chrysanthemi 3937, Mol. Microbiol. 29 (1998) 14591469.
[44] M.M. Atkinson, J. Huang, J.A. Knopp, Hypersensitivity of suspension-cultured tobacco cells to pathogenic bacteria, Phytopathology 75 (1985) 1270-1274.

[45] R.A. Dixon, M.J. Harrison, C.J. Lamb, Early events in the activation of plant defense responses, Annu. Rev. Phytopathol. 32 (1994) 479-501.

[46] Y. Mathieu, D. Lapous, S. Thomine, C. Laurière, J. Guern, Cytoplasmic acidification as an early phosphorylation-dependent response of tobacco cells to elicitors, Planta 199 (1996) 416-424.

[47] T. Xing, V.J. Higgins, E. Blumwald, Identification of $G$ proteins mediating fungal elicitor-induced dephosphorylation of host plasma membrane $\mathrm{H}^{+}$-ATPase, J. Exp. Bot. 48 (1997) 229-237.

[48] C.J. Baker, N.R. O'Neill, L.D. Keppler, E.W. Orlandi, Early responses during plant-bacteria interactions in tobacco cell-suspensions, Phytopathology 81 (1991) 1504-1507.

[49] L.D. Keppler, C.J. Baker, M.M. Atkinson, Active oxygen production during a bacteria-induced hypersensitive reaction in tobacco suspension cells, Phytopathology 79 (1989) 974-978.

[50] A. Levine, R. Tenhaken, R. Dixon, C. Lamb, $\mathrm{H}_{2} \mathrm{O}_{2}$ from the oxidative burst orchestrates the plant hypersensitive disease resistance response, Cell 79 (1994) 583-593.

[51] P.S. Low, J.R. Merida, The oxidative burst in plant defense: function and signal transduction, Physiol. Plant. 96 (1996) 533542.

[52] M.C. Mehdy, Active oxygen species in plant defense against pathogens, Plant Physiol. 105 (1994) 467-472.

[53] M.J. May, K.E. Hammond-Kosack, J.D.G. Jones, Involvement of reactive oxygen species, glutathione metabolism, and lipid peroxidation in the $C f$-gene-dependent defense response of tomato cotyledons induced by race-specific elicitors of Cladosporium fulvum, Plant Physiol. 110 (1996) 1367-1379.

[54] F. Kieffer, F. Simon-Plas, B.F. Maume, J.-P. Blein, Tobacco cells contain a protein, immunologically related to the neutrophil small $\mathrm{G}$ protein $\mathrm{Rac} 2$ and involved in elicitor-induced oxidative burst, FEBS Lett. 403 (1997) 149-153.

[55] C.J. Baker, E.W. Orlandi, N.M. Mock, Harpin, an elicitor of the hypersensitive response in tobacco caused by Erwinia amylovora, elicits active oxygen production in suspension cells, Plant Physiol. 102 (1993) $1341-1344$.

[56] D.W. Bauer, Z.-M. Wei, S.V. Beer, A. Collmer, Erwinia chrysanthemi HarpinEch: an elicitor of the hypersensitive response that contributes to soft-rot pathogenesis, Mol. Plant Microbe Interact. 8 (1995) 484-491.

[57] Z.-M. Wei, R.J. Laby, C.H. Zumoff, D.W. Bauer, S.Y. He, A. Collmer, S.V. Beer, Harpin, elicitor of the hypersensitive response produced by the plant pathogen Erwinia amylovora, Science 257 (1992) 85-88.

[58] A.V. Tiedemannm, Evidence for a primary role of active oxygen species in induction of host cell death during infection of bean leaves with Botrytis cinerea, Physiol Mol. Plant Pathol. 50 (1997) 151-166.

[59] C.J. Baker, E.W. Orlandi, Active oxygen and pathogenesis, in: G. Stacey, N.T. Keen (Eds.), Plant-Microbe Interactions, The American Phytopathological Society, St. Paul, MN, 1999, pp. 81-119.

[60] B. Klusener, E.W. Weiler, Pore-forming properties of elicitors of plant defense reactions and cellulolytic enzymes, FEBS Lett. 459 (1999) 263-266.

[61] D.G. Gilchrist, Programmed cell death in plant disease: the purpose and promise of cellular suicide, Annu. Rev. Phytopathol. 36 (1998) 393-414.

[62] J.L. Dangle, R.A. Dietrich, M.H. Richberg, Death don't have no mercy: cell death programs in plant-microbe interactions, Plant Cell 8 (1996) 1793-1807.

[63] J.T. Greenburg, Programmed cell death in plant-pathogen interactions, Annu. Rev. Plant Physiol. Plant Mol. Biol. 48 (1997) $525-545$. 